\title{
木造住宅の地震応答解析のための復元力モデルに関する研究 \\ A STUDY ON HYSTERISIS MODEL FOR EARTHQUAKE RESPONSE ANALYSIS OF TIMBER STRUCTURES
}

\author{
荒木康弘*, 腰原幹雄**, 大橋好光***, 坂本 功**** \\ Yasuhiro ARAKI, Mikio KOSHIHARA, Yoshimitsu OHASHI \\ and Isao SAKAMOTO
}

\begin{abstract}
This paper attempts to build the parameters of hysterisis models for resisting shear walls of timber structures. These parameters enables engineers to make models easily by summation of the parameters. In order to establish these parameters, this paper focuses on the following three subjects. First : Proposition of a hysterisis model fit for timber structures. Second : Proposition of parameters of the resisting shear walls, based on about 100 tests. Third : Prediction of shaking table tests from the models of summation of the walls. In the first part, the combination model of bilinear model and slip model is adopted for its simple mechanism. In the second part, the database serves for determining parameters of five different types of walls. In the third part, three models of one full-scale wooden house are proposed. The earthquake responses obtained by the models correspond to the shaking table tests, and this result confirms the accuracy of the parameters.
\end{abstract}

Keywords: Hysterisis model, DataBase, Summation of parameters of Hysterisis model, Earthquake response analysis 復元カモデル、データベース、復元カモデルの重㸚合わせ、地震応答解析

\section{1.はじめに}

1995 年兵庫県南部地震における木造住宅の被害数は約 39 万棟、 そのうち約 10 万棟が全壊という甚大な被害であり、震災後、その 耐震性に疑問がもたれた。その後の数例の振動台実験 1)-3)を通して、 木造住宅を耐震的に強くできることは確認されたが、課題も残され ている。建物の地震時の動的性能は確認できたが、それを解析的に 把握するには構造物の復元力特性のモデル化が必要となる。実大建 物の復元力モデルは、実大振動台実験から得ることが最も理想的で あろうが、それには相応の設備と費用が必要となる。一方、木造住 宅では耐力要素は一般的に壁であり、また耐力壁実験であれば比較 的容易に行える。これらを考慮すると、耐力壁の復元力モデルの重 初合わせから建物全体の動的举動が把握できるならば、それは非常 に合理的な方法であると考えられる。また壁の仕様ごとに復元力モ デルが決定されていれば、任意の壁の組み合わせの構造物に対し、 復元力モデルを決定することができる。

木造住宅の耐震性、特に地震応答解析に関する既往の研究として、 耐力壁および層レベルの復元力モデルについては多数の復元力モデ ルが用いられている。坂本・大橋 1)によるバイリニア+スリップモ デルや、宮澤らによるディグレーディング・トリリニア（D:Tri）モ デル、荷重変形曲線を忠実に再現するモデルとして、坂本・大橋 6 ) によるモデル、真柄・三宅てによるモデル、安村 》によよるモデルが 提案されている。また、耐力壁の重初合わせから実大建物の復元力 モデルを予測する点に関しては、宮澤ら91は枠組壁工法住宅につい て酎力壁の静的立体弾塑性応力解析の結果から建物の復元力モデル の予測を行い、実大振動実験結果と解析結果の検証を行い、尾内 ・
太田 ${ }^{10)}$ らは、壁の静的加力実験による復元力特性を建物全体系の振 動特性と組み合わせて振動モデルを作成し、建物の常時微動特性を このモデルに反映させて地震時の応答を推算し、被害状況と照合し て耐震性評価を行っている。

しかしながら、これらの復元力モデルについてモデルのバラメタ を決定する必要があるが、いずれの場合も試験体毎に決定するのみ であり、パラメタに関する統合的な考察は行われていない。また、 『実大建物の復元力特性が耐力壁の復元力特性の和になる』という 仮定について、復元カモデルのパラメタを用いてそれを実証した前 例はない。本論文の目的は、多数の実験デー夕に基づき復元力モデ ルのパラメ夕を提案し、それら提案した復元力モデルの重ね合わせ により、実大建物の復元力モデルを予測する手法を提案することで ある。多数の実験デー夕に基づき復元力モデルのパラメ夕を提案す る点で、本研究は上記の研究と軌を一にするものであり、またこの 手法が確立されれば、設計者が容易に建物の復元力モデルを作成し、 地震応答解析による耐震性の検討を行うことが可能となる。

\section{2. 研究の方針}

前章で主たる流れを示したが、各論を述べるに先立ち、本研究の 全体的な流れについて以下の各項と図 1 に示す。

（1）壁の復元力特性の設定 : 本研究では復元力モデルとしてバイ リニアナスリップモデルを用いた。

（2）耐力壁実験データの収集：バラメタの提案を行うために壁実 験結果を収集し、データベースを作成した。筆者らが収集し
* 東京大学大学院 工修

** 東京大学大学院工学系研究科 助手. 工博

*** 熊本県立大学 助教授・工博

***** 東京大学大学院工学系研究科 教授. 工博
Graduate School of Eng. Univ. of Tokyo, M. Eng.

Research Assoc., Graduate School of Eng. Univ. of Tokyo, Dr. Eng.

Assoc. Prof., Prefectural University of Kumamoto, Dr. Eng

Prof., Graduate School of Eng. Univ. of Tokyo, Dr. Eng. 
たデータ（以下「実験データ」と記す）は、筆者らの実験結果、

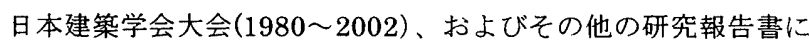
掲載された論文・資料等い 199から収集したものである。

（3）復元力モデルのパラメタの提案 : 作成したデータベースを用い てパラメタの提案を行った。決定に際しては、パラメタに影響を 与えると考えられる実験条件および試験体の仕様との関係につ いて考察を行った。

（4）実大建物の復元力モデルの予測：提案したパラメタの重ね合わ せにより、実大建物の復元カモデルを予測した。その際に、有開 口壁の予測法および構面の壁の復元力モデルの重ね合わせから 実大建物の復元力モデルの予測手法を提案した。

（5）地震応答解析によるパラメタの検証：予測した復元力モデルを 用いて地震応答解析を行い、応答結果と実大振動台実験結果を検 討し、提案したモデルの妥当性を確認した。

なお、壁試験体の長さは半間 $(910 \mathrm{~mm})$ を 1 単位（以下「 $1 \mathrm{P} J$ )、変 形角の単位を $\mathrm{mrad} .(=1 / 1000 \mathrm{rad}$.$) として以下の議論を進める。$

\section{3. 復元カモデルの作成}

本研究では、壁の復元力特性としてバイリニア+スリップモデル を用いた(図 2)。その理由としては、その復元力特性が単純で操作し やすい点、また「ピンチング」という木質構造物の復元力特性に特 徵的な現象を再現することができる点、そして既往の研究において

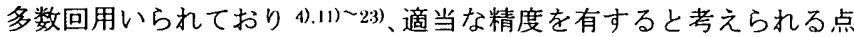
が挙げられる。

次にモデルの決定過程を以下の各項と図 5 に示す。

（1）実験値の荷重変形曲線から包絡線（ $\mathrm{SC}_{\mathrm{test}}$ : 図 3 (1) を決定し、 そこから復元力モデルの骨格となるトリリニアの包絡線モデル $\left(\mathrm{SC}_{\text {molel }}\right.$ : 図 3 (2) ) を決定する。 $\mathrm{SC}_{\text {model }}$ の第 1 折点 (変形角 $y_{\mathrm{L}}$

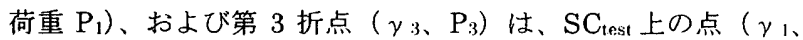
$\left.P_{1}\right)$ および $\left(\gamma_{3} 、 P_{3}\right)$ とする。本研究において、 $\gamma_{1}$ については 2mrad.とした。その理由としては、木質構造物における荷重変 形関倸は、明確な損傷が確認できないまま非線形性を示すため適 当に決定する必要があるためである。 $\gamma_{3}$ については、多数の㬰 験データから壁の仕様ごとに設定した。また最大耐力経験後 ( $\gamma_{3}$ $\leqq \gamma)$ 剛性については一定とした。これは、本研究では崩壊時 の挙動について論じないためである。

(2) $y_{1}<\gamma_{2}<\gamma_{3}$ となるような $\gamma_{2}$ をパラメタとして、 $\mathrm{SC}_{\mathrm{test} 1}$ と $\mathrm{SC}_{\text {model }}$ の吸収エネルギーの間に $\mathrm{E}_{\mathrm{test} \text { ! }}=\mathrm{E}_{\text {model } 1}$ の関係が成立する ように $\mathrm{SC}_{\text {mollel }}$ の第 2 折点 $\left(\gamma_{2} 、 \mathrm{P}_{2}\right)$ を決定する。

この包絡線モデルの各剛性(第 1、第 2 、第 3 剛性)とバイリ二 ア要素およびスリップ要素の各剛性との間には

$$
\begin{aligned}
& \text { 第 } 1 \text { 擂性 }=\mathrm{K}_{\mathrm{b} 1}+\mathrm{K}_{\mathrm{s1}} \\
& \text { 第 } 2 \text { 剛性 }=\mathrm{K}_{\mathrm{b} 2}+\mathrm{K}_{\mathrm{s1}} \text { or } \mathrm{K}_{\mathrm{b} 1}+\mathrm{K}_{42} \\
& \text { 第 } 3 \text { 剛性 }=K_{b 2}+K_{s 2}
\end{aligned}
$$

という関係が成立する。これより復元力モデルは大別して、第 2 剛性が $\mathrm{K}_{\mathrm{b} 2}+\mathrm{K}_{\mathrm{s} 1}$ となるもの、すなわちバイリニア先行降伏型と

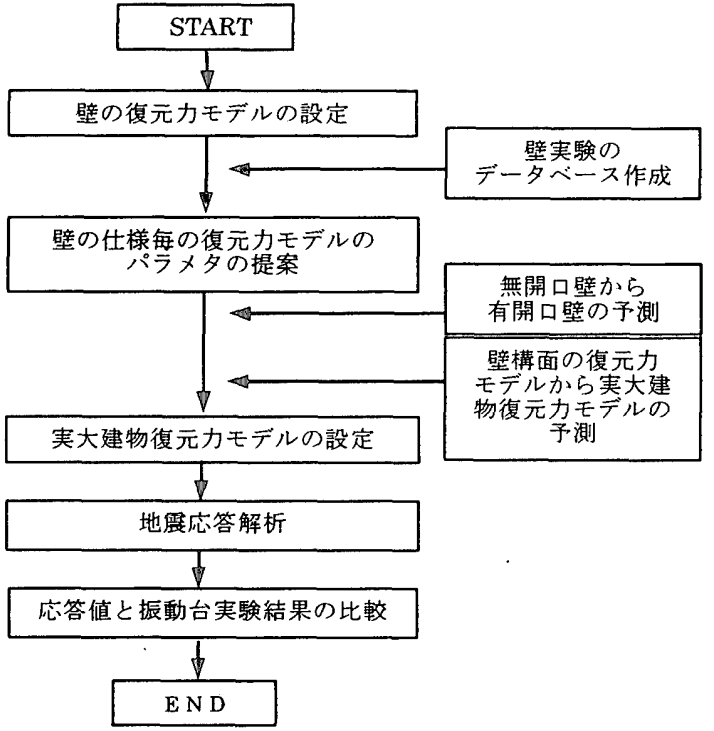

図 1 研究の方針
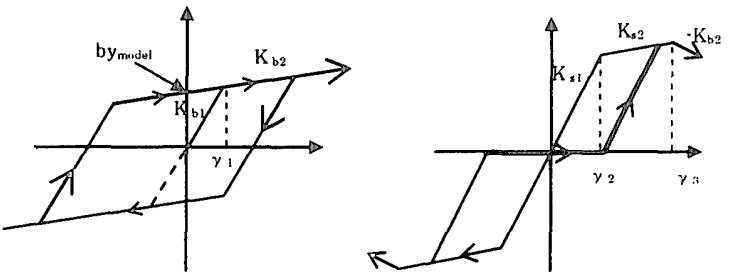

バイリニア要素

スリップ要素

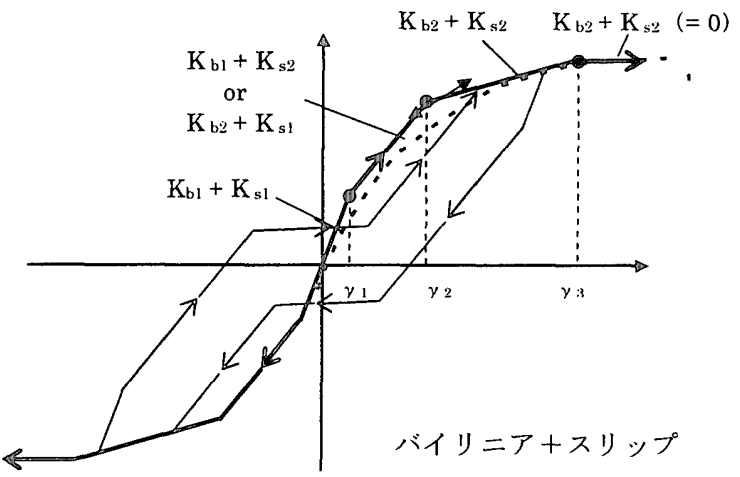

図 2 バイリニア+スリップモデルと各剛性の関係

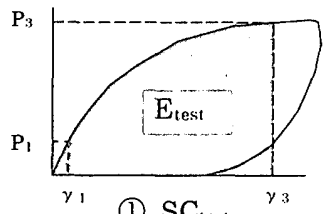

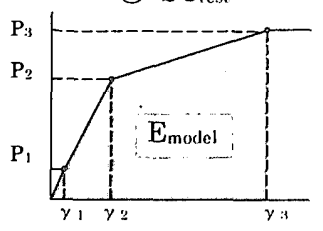

(2) $\mathrm{SC}_{\text {molel }}$

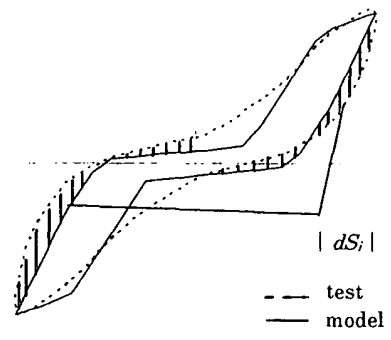

図 4 適合度
図 3 吸収エネルギー

$\mathrm{K}_{\mathrm{b} 1}+\mathrm{K}_{\mathrm{s} 2}$ となるもの、すなわちスリップ先行降伏型の 2 種類が 考えられる(図 2)。

（3）この両者のモデルについて、4つの㐩性のうちの 1 つを仮定し、 (1) （3)式に従って他の 3 つの剛性を決定する。本研究では $\mathrm{K}_{\mathrm{b} 2}$ 
をパラメタとした。

（4）第 $\mathrm{i} ル ー フ ゚(n \leqq i \leqq N 、 n ：$ 当該ループの最大変形角が最初に 2mrad.を超えるループ番号、 $\mathrm{N}$ : 最終ループ番号)の時の戻り勾 配部分の、各変形角における赛験の耐力とモデルの耐力の差の絶 対値の和（=|dS $\mid$ 、図 4) と、実験值における第 i ループの戻 り勾配部分の耐力の和の絶対值 (=|Stest $\left.i_{i} \mid\right)$ を求める。この とき、第 $\mathrm{i}$ ループの実験值に対する復元力モデルの『適合度』 $M_{i}$ を次式で定義する。

$$
M_{i}=\frac{\mid \text { Stest }_{i}|-| d \dot{S}_{i} \mid}{\mid \text { Stest }_{i} \mid}(\%)
$$

各ループにおける適合度の和 $\sum M_{i}$ が最大となるときの第 2 折点 および各剛性の組合せを、実験結果に対する復元力モデルとする。 復元力モデルは、包絡線モデルの各剛性(第 1〜第 3 剛性)、第 2 折点、第 3 折点、およびモデルの第 1 㴊性 $\left(\mathrm{K}_{\mathrm{b} 1}+\mathrm{K}_{\mathrm{s} 1}\right)$ に対するバ イリニア要素の第 1 剛性 $\left(=\mathrm{K}_{\mathrm{b} 1}\right)$ の割合が決定すれば作成可能で ある。そこでこれらのパラメタを以下のように定義し、(4)で決定し た各剛性の関係をこれらのパラメタを用いて表した。

(1) 第 1 剛性に対するバイリニア要素の第 1 剛性の割合を $a$

$a=\mathrm{K}_{\mathrm{b} 1} /\left(\mathrm{K}_{\mathrm{b}, 1}+\mathrm{K}_{\mathrm{s} 1}\right)$

(2) 第 1 剛性に対する第 2 剛性の割合を $b$ :

$b=\left(\mathrm{K}_{\mathrm{b} 2}+\mathrm{K}_{\mathrm{s} 1}\right.$ or $\left.\mathrm{K}_{\mathrm{b} 1}+\mathrm{K}_{\mathrm{s} 2}\right) /\left(\mathrm{K}_{\mathrm{b} 1}+\mathrm{K}_{\mathrm{s} 1}\right)$

(3) 第 1 剛性に対する第 3 剛性の割合を $c$ :

$c=\left(\mathrm{K}_{\mathrm{b} 2}+\mathrm{K}_{\mathrm{s} 2}\right) /\left(\mathrm{K}_{\mathrm{b} 1}+\mathrm{K}_{\mathrm{s} 1}\right)$

このとき(4)式において、|Stest $t_{j} \mid$ は、実験結果の第 i ループの 荷重変形曲線で囲まれる部分の面積（エネルギー）を表し、パラメ 夕 $a 、 b 、 c$ の影響は受けない。一方 $\left|d S_{j}\right|$ は、図 4 からもわかる ように復元力モデルのループの形状により変化する。従って、 $M_{i}$ の値は復元力モデルのバラメタ $a 、 b 、 c$ 影響のみを受ける。

\section{4. 復元カモデルのパラメタの提案}

作成した壁実験のデータベースを用いて復元力モデルのパラメタ の提案を行った。以下にバラメタを決定するまでの過程を示す。

（1）収集した実験データに対し復元力モデルを作成する。

（2）壁の仕様ごとに復元力モデルを分類する。本論文では特に筋交 (10)、構造用合板(15)、石骨ボード(9)、軸組十石誵ボード(10)、

軸組十石膏ボード+サイディング(9)の 5 種類の壁について、パ ラメタの提案を行う(括弧内の数字はデータ数を表す)。

（3）分類したモデルのパラメタと、壁の仕様および実験条件との関 係について考察を行う。バラメ夕に影響を与える因子として、 既往の研究 241299)上り、壁の仕様については、釘打仕様、柱頭・ 柱脚の固定方法、壁幅、開口形状について、実験条件について は、試験体固定方法、積載方法および積載荷重の有無を举げる。

（4）（3)の考察を考慮して、壁の仕様および実験方法に対する復元力 モデルのバラメタの提案を行う。

なお、(3)における考察の結果、釘打仕様、柱頭・柱脚の固定方法、 開口形状がバラメ夕に影響を与える主な因子と考えられた。そのた め、(4)においてはこれらの因子を考慮してパラメ夕の提案を行った。

一例として、、表 1 に構造用合板（データ数 15）の各仕様（壁幅、 面材数、板厚、開口形状、柱脚金物、積載荷重、釘打間隔）および 復元力モデルの各バラメタ（第 1 、第 $2 、$ 第 3 剛性、 $a 、 b 、 c 、$ 第 $2 、$

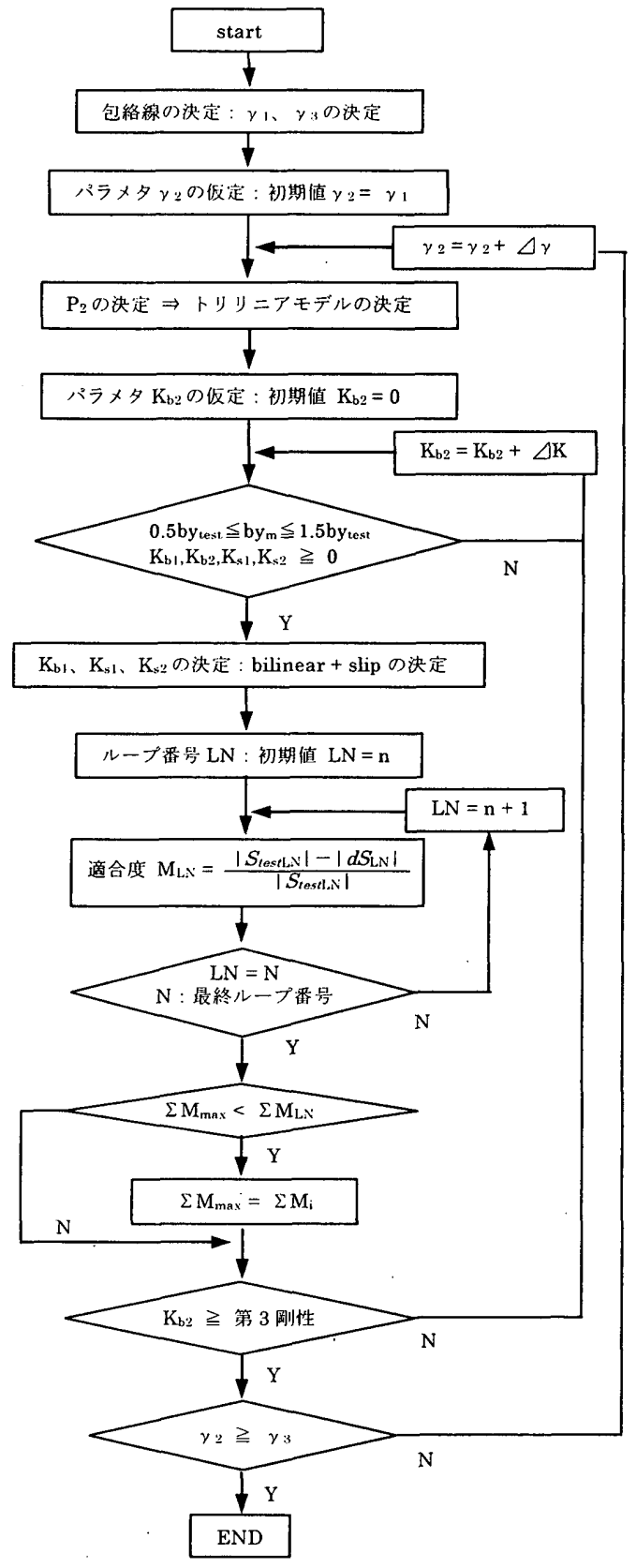

図 5 復元力モデルの決定フロー

第 3 折点）を示す。これらパラメタと、壁の仕様および実験条件と の関係について行った考察について以下に示す。

(1) 柱頭・柱脚に HD 金物を用いた仕様(PW-1-1,PW-1-2 以外)と用 いていない仕様とでは、 $a 、 b 、 c に$ 差異はない。

(2) 釷間隔について、 $a 、 b$ については釷間隔に関わらず $a$ は 0.3 $\sim 0.5 、 b$ は $0.6 \sim 0.7$ 程度、 $c$ については、釘間隔のやや広い仕 様(@150 前後)では 0.05 0.1 程度、釘間隔の狭い仕様(@100 以下)では 0.1 程度である。

(3) 第 2 折点については、無開口壁で HD 金物を用いた仕様 (PW-2N-1〜PW-2N-6)では 4.5〜6.5mrad.であるのに対し、 $\mathrm{HD}$ 金物を用いない場合(PW-1-1,PW-1-2)は 10mrad.程度であ る。また、釷間隔の狭い仕様 $(\mathrm{PW}-2 \mathrm{~N}-1 \sim \mathrm{PW}-2 \mathrm{~N}-6)$ では 4.5〜 $6.5 \mathrm{mrad}$.であるのに対し、釘間隔のやや広い仕様 $(\mathrm{PW} \cdot 1 \cdot 1, \mathrm{PW}$ 1-2)では $10 \mathrm{mrad}$.程度であった。これより脚部の固定度、釘打 
表 1 構造用合板の仕様および復元力モデルのバラメタ

\begin{tabular}{|c|c|c|c|c|c|c|c|c|c|c|c|c|c|c|c|c|}
\hline \multirow[t]{2}{*}{$\vec{F}-$ 名名 } & \multirow{2}{*}{ 壁蝠 } & \multirow{2}{*}{ 面财数 } & \multirow{2}{*}{$\begin{array}{l}\text { 板厚 } \\
(\mathrm{mm})\end{array}$} & \multirow{2}{*}{$\begin{array}{l}\text { 盟山 } \\
\text { 斨状 }\end{array}$} & \multirow{2}{*}{$\begin{array}{l}\text { HD } \\
\text { 金物 }\end{array}$} & \multirow{2}{*}{ 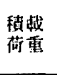 } & \multicolumn{2}{|c|}{ 邹間隔 $(\mathrm{mm})$} & \multirow{2}{*}{$\begin{array}{l}\text { 第 } 1 \\
\text { 性性 }\end{array}$} & \multirow{2}{*}{$\begin{array}{l}\text { 第 } 2 \\
\text { 刷性" }\end{array}$} & \multirow{2}{*}{ 第 3} & \multirow[b]{2}{*}{ a } & \multirow{2}{*}{$b$} & \multirow{2}{*}{$c$} & \multirow{2}{*}{$\begin{array}{l}\text { 笨 } 2 \\
\text { 点 }\end{array}$} & \multirow{2}{*}{$\begin{array}{l}\text { 䇽3 } \\
\text { 点 }\end{array}$} \\
\hline & & & & & & & 外周(链) & 中枠阵) & & & & & & & & \\
\hline$P W \cdot 1 \cdot 1$ & IP & $\pi^{\prime}$ & 9 & 魝開以 & 然 & 哭 & 100 & 200 & 0.82 & 0.60 & 0.07 & 0.34 & 0.74 & 0.08 & 10.00 & 33 \\
\hline PW.1-2 & IP & 片 & 9 & 無開口 & 無 & 有 & 150 & 150 & 0.80 & 0.48 & 0.01 & 0.41 & 0.59 & 0.01 & 9.00 & 20 \\
\hline $\mathrm{PW}-2 \mathrm{~N}-1$ & $2 \mathrm{P}$ & $\mu_{5}$ & 12.5 & 無開山 & 有 & 無 & 75 & 75 & 6.58 & 3.59 & 0.84 & 0.48 & 0.55 & 0.13 & 5.50 & 33 \\
\hline $\mathrm{PW} \cdot 2 \mathrm{~N} \cdot 2$ & $2 \mathrm{P}$ & 片 & 12.5 & 無開口 & 有 & 邫 & 100 & 100 & 5.69 & 4.00 & 0.32 & 0.32 & 0.70 & 0.06 & 4.40 & 33 \\
\hline$P W \cdot 2 N-3$ & $2 \mathrm{P}$ & 片 & 12.5 & 羖聞口 & 有 & 無 & 100 & 100 & 1.88 & 1.13 & 0.04 & 0.42 & 0.60 & 0.02 & 5.90 & 33 \\
\hline $\mathrm{PW} \cdot 2 \mathrm{~N} \cdot 4$ & $2 \mathrm{P}$ & 兩 & 7.5 & 無硼口 & 有 & 有 & 100 & 200 & 4.56 & 2.98 & 0.52 & 0.38 & 0.65 & 0.11 & 6.20 & 33 \\
\hline PW'2N-5 & $2 \mathrm{P}$ & $5^{2}$ & 12.5 & 無開口 & 有 & 無 & 50 & 50 & 7.12 & 4.87 & 0.62 & 0.34 & 0.68 & 0.09 & 5.90 & 33 \\
\hline $\mathrm{PW} \cdot 2 \mathrm{~N}-6$ & $2 \mathrm{P}$ & 片 & 12.5 & 無開口 & 有 & 無 & 60 & 60 & 7.70 & 5.33 & 0.56 & 0.34 & 0.69 & 0.07 & 5.30 & 33 \\
\hline $\mathrm{PW} \cdot 4 \mathrm{C} \cdot 1$ & $4 \mathrm{P}$ & $\pi^{\prime}$ & 12.5 & 阿蝡 & 有 & 無 & 150 & 150 & 0.81 & 0.57 & 0.06 & 0.32 & 0.71 & 0.07 & 4.10 & 33 \\
\hline $\mathrm{PW} \cdot 4 \mathrm{~A} \cdot 1$ & $4 \mathrm{P}$ & $n^{\prime}$ & 12.5 & 中央 $2 \mathrm{P}$ & 有 & 無 & 150 & 150 & 0.70 & 0.36 & 0.06 & 0.56 & 0.52 & 0.09 & 5.40 & 33 \\
\hline $\mathrm{PW} \cdot 4 \mathrm{~W} \cdot 1$ & $4 \mathrm{P}$ & 5 & 12.5 & 空型 & 有 & $\begin{array}{l}\text { 無 } \\
\end{array}$ & 150 & 150 & 1.24 & 0.88 & 0.06 & 0.31 & 0.71 & 0.05 & 5.80 & 33 \\
\hline$P W \cdot 2 W-1$ & $2 P$ & $\pi$ & 12.5 & 空型 & 有 & 無 & 75 & 75 & 6.76 & 3.76 & 0.90 & 0.49 & 0.56 & 0.13 & 7.10 & 33 \\
\hline $\mathrm{PW} \cdot 4 \mathrm{~W}-2$ & $4 \mathrm{P}$ & 雨 & 7.5 & 㤎型 & 有 & 有 & 100 & 200 & 5.07 & 3.17 & 0.69 & 0.39 & 0.63 & 0.14 & 7.00 & 33 \\
\hline $\mathrm{PW} \cdot 4 \mathrm{D} \cdot 1$ & $4 \mathrm{P}$ & 片 & 12.5 & 墇出 & 有 & 隐 & 150 & 150 & 0.90 & 0.60 & 0.08 & 0.35 & 0.67 & 0.09 & 5.70 & 33 \\
\hline$P W \cdot 2 D \cdot 1$ & $2 \mathrm{P}$ & $f^{2}$ & 12.5 & 挡出 & 有 & 䊂 & 75 & 75 & 3.75 & 2.17 & 0.46 & 0.45 & 0.58 & 0.12 & 8.50 & 33 \\
\hline
\end{tabular}

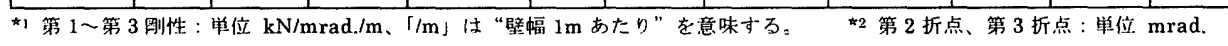

表 2 各壁の仕様および復元力モデルのパラメタ

\begin{tabular}{|c|c|c|c|c|c|c|c|c|c|c|}
\hline & 壁幅 & 管交訨滕 & 開口形犾 & HD 金物 & $a$ & $b$ & $c$ & $\begin{array}{c}\text { 第2 } 2 \text { 折点 } \\
\text { (mrad. }\end{array}$ & $\begin{array}{l}\text { 第 } 3 \text { 折点 } \\
\text { (mrad.) }\end{array}$ & 第 1 刷性 $(\mathrm{kN} / \mathrm{mrad} / \mathrm{m})$ \\
\hline \multirow{5}{*}{ 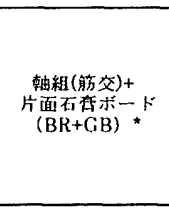 } & \multirow{3}{*}{$4 \mathrm{P}(8 \mathrm{P})$} & \multirow{3}{*}{ - } & 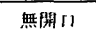 & \multirow{3}{*}{ 有 } & \multirow{3}{*}{0.35} & \multirow{3}{*}{0.7} & \multirow{3}{*}{0.15} & $4.0(5.0)$ & \multirow{3}{*}{30} & $4.5^{*}$ \\
\hline & & & 捂出 & & & & & $5.0(6.0)$ & & $3.2^{* *}$ \\
\hline & & & 空型 & & & & & $4.5(5.5)$ & & $3.7^{* *}$ \\
\hline & $\mathrm{IP}$ & 片肪公 & 諎開 11 & 有 & 0.48 & 0.62 & 0.10 & 5.5 & 30 & 1.4 \\
\hline & IP & 両鋂交 & 無閍 & 有 & 0.45 & 0.65 & 0.15 & 7.5 & 30 & 1.6 \\
\hline \multirow{5}{*}{ 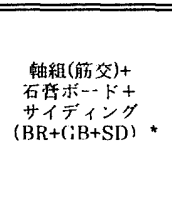 } & \multirow{3}{*}{$\begin{array}{l}4 \mathrm{P} \\
8 \mathrm{P}\end{array}$} & \multirow{3}{*}{ - } & 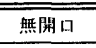 & \multirow{3}{*}{ 䏍 } & \multirow{3}{*}{0.4} & \multirow{3}{*}{0.65} & \multirow{3}{*}{0.15} & 5 & \multirow{3}{*}{30} & $6^{\star \star \star}$ \\
\hline & & & 招出 & & & & & 6 & & $4^{* *}$ \\
\hline & & & 空型 & & & & & 5.5 & & $5^{* *}$ \\
\hline & $1 \mathrm{P}$ & 片䑻交 & 無阴 & 有 & 0.35 & 0.70 & 0.10 & 5.5 & 30 & 2.0 \\
\hline & $1 \mathrm{P}$ & 両艁交 & 㷦開い & 有 & 0.30 & 0.70 & 0.15 & 6.0 & 30 & 2.1 \\
\hline 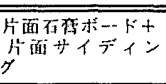 & IP & 照 & 無開い & 们 & 0.20 & 0.82 & 0.03 & 5.0 & 30 & 1.4 \\
\hline
\end{tabular}

\begin{tabular}{|c|c|c|c|c|c|c|c|c|c|c|c|}
\hline & \multirow{2}{*}{ 裀财数 } & \multirow{2}{*}{ 壁湢 } & \multicolumn{2}{|c|}{ 钓間|隔 $(\mathrm{mm})$} & \multirow{2}{*}{110 金物 } & \multirow{2}{*}{$a$} & \multirow{2}{*}{$b$} & \multirow{2}{*}{$c$} & \multirow{2}{*}{$\begin{array}{c}\text { 第2 } 2 \text { 折点 } \\
\text { (mrall.) }\end{array}$} & \multirow{2}{*}{$\begin{array}{l}\text { 第 } 3 \text { 折点 } \\
\text { (mra..) }\end{array}$} & \multirow{2}{*}{ 第 1 刷性 $(\mathrm{kN} / \mathrm{mrad} / \mathrm{m})$} \\
\hline & & & 外周(綐) & 中愤(徙) & & & & & & & \\
\hline \multirow{4}{*}{ 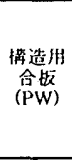 } & 片洏 & $1 \mathrm{P}$ & 100 & 100 & 有 & 0.37 & 0.65 & 0.05 & 5.5 & 33 & 2.2 \\
\hline & 汕活前 & IP & 100 & 200 & 有 & \multirow{3}{*}{0.37} & \multirow{3}{*}{0.65} & \multirow{3}{*}{0.1} & \multirow{3}{*}{5.5} & \multirow{3}{*}{33} & 2.5 \\
\hline & & IP & 75 & 75 & 位 & & & & & & 2.7 \\
\hline & 片汿 & $1 \mathrm{P}$ & 50 & 50 & 有 & & & & & & 2.9 \\
\hline \multirow{7}{*}{ 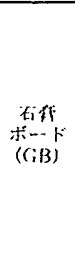 } & \multirow{4}{*}{ Hitri } & $\mathrm{IP}$ & 100 & 200 & $\begin{array}{lll}\text { 無 } \\
\end{array}$ & 0.4 & 0.65 & 0.08 & 6 & \multirow{7}{*}{20} & 0.9 \\
\hline & & $1 \mathrm{P}$ & 100 & 150 & 有 & \multirow{3}{*}{0.4} & \multirow{3}{*}{0.65} & \multirow{3}{*}{0.08} & 3.5 & & 1 \\
\hline & & $1 \mathrm{P}$ & 150 & 150 & 们 & & & & 3.5 & & 0.9 \\
\hline & & $1 \mathrm{P}$ & 100 & 200 & 有 & & & & 3.5 & & 1.1 \\
\hline & \multirow{3}{*}{ 雨洏 } & $1 \mathrm{P}$ & 100 & 150 & 有 & \multirow{3}{*}{0.28} & \multirow{3}{*}{0.75} & \multirow{3}{*}{0.05} & 3.5 & & 2 \\
\hline & & $1 \mathrm{P}$ & 150 & 150 & 南 & & & & 3.5 & & 1.8 \\
\hline & & $1 \mathrm{P}$ & 100 & 200 & 佇 & & & & 3.5 & & 2.1 \\
\hline
\end{tabular}

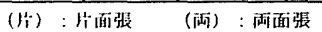

\begin{tabular}{|c|c|c|c|c|c|c|c|c|c|c|}
\hline & 解父化增 & 壁幅 & 第交端部 & IID 金物 & $a$ & $b$ & : & $\begin{array}{l}\text { 第 } 2 \text { 折点 } \\
\text { (mrad.) }\end{array}$ & $\begin{array}{c}\text { 第 } 3 \text { 折点 } \\
\text { (mrad.) }\end{array}$ & 第 1 即性 $(\mathrm{kN} / \mathrm{mrarl} / \mathrm{m})$ \\
\hline \multirow{2}{*}{$\begin{array}{l}\text { 能父 } \\
\text { (BR) }\end{array}$} & 战施父 & IP & 筋父 PL & 们 & 0.35 & 0.7 & 0.05 & 7 & 15 & 0.8 \\
\hline & 屾萠父 & $1 P$ & 的交 $\mathrm{Pl}$ & 佮 & 0.45 & 0.7 & 0.15 & 8.5 & 15 & 1.4 \\
\hline
\end{tabular}

仕様は第 2 折点に影響を与えると考えられる。

以上の結果を踏まえて、構造用合板のバラメタを表 2 のように設 定した。 $a 、 b$ 、第 2 折点は壁の仕様によらず一定、cは釷の多い仕

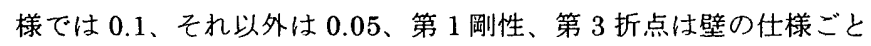
に決定した。

4 (2)にに示した他の 4 種類の壁についても同様の検討を行った。
その結果を同じく表 2 に示す。

作成した復元力モデルのパラメタについて、前章の適合度を用い て作成したモデルの第 2 勾配は全て $K_{\mathrm{b} 2}+\mathrm{K}_{\mathrm{s} 1}$ 、寸なわちバイリ二 ア先行降伏型となった。これは、木質構造物の履歴ループに特徵的 な逆 $\mathrm{S}$ 字の形状に復元力モデルが適合するには、バイリニア先行降 伏型であることが必要であることを示唆している。また耐力低下の 要因となる試験体の接合部等の損傷と第 2 折点の関係について、損 
傷はほとんど 10mrad.以降に集中していたのに対し、復元力モデル の第 2 折点はおよそ $5 \mathrm{mrad}$.前後に集中していることから、本モデ ルでは損傷と第 2 折点との間には関連性はみられないと考えられる。

\section{5. 壁要素の復元カモデルから実大建物復元カモデルの予測 5.1 対象建物}

提案した壁の復元力モデル（以下「要素モデル」）を用いて、実大 建物の復元力モデル（以下「実大モデル」）を、 $1 \mathrm{P}$ 試験体および 4 . $8 \mathrm{P}$ 試験体から作成した要素モデル（以下「1 Pモデル」および「4・ $8 \mathrm{P}$ モデル」）の重ね合わせから予測した。想定する試験体 9) と 3 種 類のモデルを図 6 と以下の(1)〜(3)に示す。

（1） M-1：実大静加力実験結果から作成

(2) $\mathrm{M}-2: 4 \cdot 8 \mathrm{P}$ モデルの重ね合わせから作成

（3） M-3：1 P モデルの重ね合わせから作成

実大建物の平面形状はいわゆる田の字型平面、外壁は軸組に室内 側に石疊ボード、室外側にサイディングを張った仕様、内壁は軸組 に両面石敦ボードを張った仕様である。またパラメタの決定には、 表 2 における同仕様のパラメタを用いた。

$1 \mathrm{P}$ モデルから $4 \cdot 8 \mathrm{P}$ モデル・実大モデルの予測の際には、開口 形状の影響、および重悋合わせた際にパラメ夕を決定する必要があ る。以下にそれらの決定方法を示す。

\section{2 有開口耐力壁の予測}

3 章で述べたように、 $a 、 b 、 c$ および第 2 折点が提案されている 場合、第 1 剛性が決定すれば他の剛性は決定され、復元力モデルを 決定できる。無開口壁については、4P p 8P 壁の第 1 剛性は、1P 壁の重ね合わせがほほ成り立つが、有開口壁では成り立たない。そ こで、有開口耐力壁の第 1 剛性を以下のように推定した。

枠組壁工法の有開口耐力壁の耐力推定法としては、次式に示寸杉 山3(0)らによる式（以下杉山式とする）がある(図 7)。

$$
r=\left(\frac{1}{1+(\alpha / \beta)}\right)
$$

$r$ ：耐力低下因子（シージングエリア倸数）

$$
\alpha: \frac{A_{0}}{H \cdot L}
$$

$$
\beta: \sum L_{i} / L
$$

$$
\mathrm{A}_{0} \text { : 開口面積 } \mathrm{H} \text { : 耐力壁高さ }
$$

$\mathrm{Li}$ ：耐力壁部分の長さ $\mathrm{L}$ ：壁の全長

$$
F(1 / 300)=\frac{3 r}{5-2 r}
$$

: $3.3 \mathrm{mrad} .(=1 / 300 \mathrm{rad}$.$) 時の耐力比（=有開口 / 無開口）$

この杉山式を軸組構法の有開口耐力壁に適用すると、実際の耐力 比よりもかなり安全側に評価される。鉿木も、「杉山式は枠組壁工法 を対象とした実験式であり、軸組構法に適用した場合安全側に過大 に評価する」と述べている31)。図 8 に示すように、複数の軸組構法 有開口耐力壁 91. 13). 16). 17にについて $r$ と $F$ の関倸を求めた結果、杉山 式の $\mathrm{F}(1 / 300)$ を 1.35 倍したものが良く適合したため、軸組系では $\mathrm{F}(1 / 300)$ に 1.35 を乗じたものを採用した。

一例として、図6の1P モデルから $8 \mathrm{P}$ モデルを予測方法を示す。

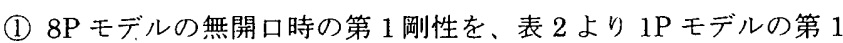
甽性の和から決定する。

第 1 剛性 $=(2.0+2.1+1.4 \times 2) \times 0.91 \times 2=12.56(\mathrm{kN} / \mathrm{mrad}$.

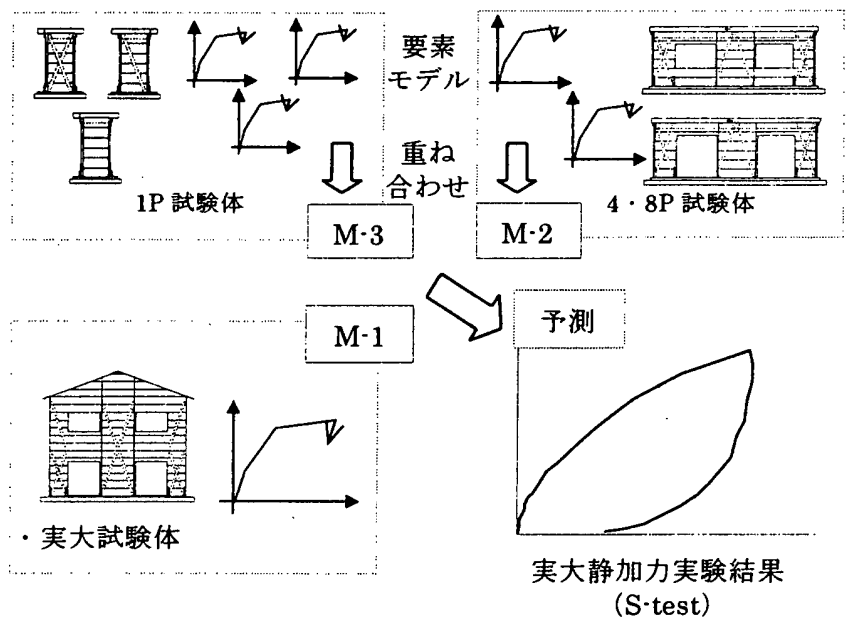

図 6 各試験体の復元力モデルの重ね合わせ方法

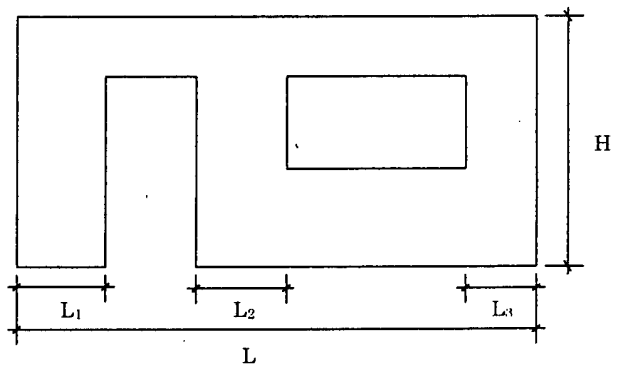

図 7 杉山式の想定する有開口耐力壁

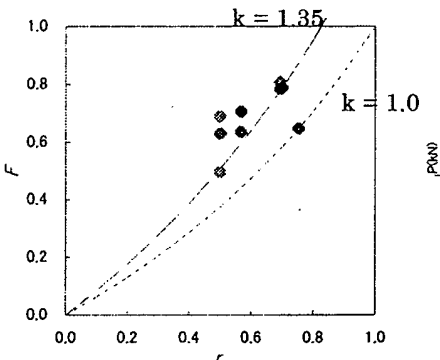

図 8 軸組構法有開口壁の 耐力比 $F$

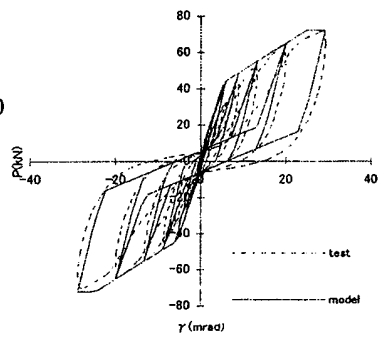

図 $98 \mathrm{P}$ モデルの予測
(2) 開口形状による低減率を修正した杉山式から求め、開口時の第 1 剛性を決定する。

耐力比は、空型：0.78、掃出型：0.59 第 1 剛性 $(\mathrm{kN} / \mathrm{mrad}$.)は、空型 : 9.83、掃出型 : 7.41

(3) 提案したパラメタより第 $2 、$ 第 3 剛性を決定する。

空型、掃出型 $: b=0.7 、 c=0.15$ より

空型 : 第 2 剛性 $=6.88(\mathrm{kN} / \mathrm{mrad}$.)、第 3 剛性 $=1.47(\mathrm{kN} / \mathrm{mrad}$.) 掃出型: 第 2 剛性 $=5.19(\mathrm{kN} / \mathrm{mrad}$.)、第 3 剛性 $=1.11(\mathrm{kN} / \mathrm{mrad}$. また表 2 より、第 2 折点は $5.5 \mathrm{mrad}$ 、第 3 折点は $30 \mathrm{mrad}$.とな る。決定した復元力モデルと実験結果の荷重变形曲線を図 9 に示す。

\section{3 要素モデルの重ね合わせによる実大モデルの予測}

要素モデルのバラメタの重ね合わせにより、実大モデルを作成す るが、その際、実大モデルの $a$ および第 2 折点は重ね合わせる数だ け考えられる。aについてはそれらの平均值 $\left(a_{\text {mmen }}=\Sigma a_{i} / N 1\right.$ $\leqq i \leqq N \quad N$ : 重ね合わせる要素モデル数）を用いた。また第 2 
折点 $\left(\gamma_{2} 、 \mathrm{P}_{2}\right)$ については、重ね合わせる要素モデルの吸收エネル ギ一の和（ $\Sigma E_{i} ）$ が、実大モデルの吸収エネルギー $\left(E_{\text {sum }}\right)$ に等 しくなる $\left(E_{\text {sum }}=\Sigma E_{j}\right)$ ような第 2 折点を決定した。

\section{4 包絡線と復元カモデルの比較}

図 10 に実大静加力実験結果（以下 S-test）の包絡線と 3 種類の 復元カモデルの包絡線モデルを、表 3 に各モデルのパラメタの值を 示す。表 3 および図 10 より、M-2 は第 1 剛性および第 2 剛性は M-1 に近いが、第 2 折点が M-1 に比べ大きく S-testよりもややふ くらんだ包絡線となる。一方 M-3 は、第 1 剛性および第 2 剛性が $\mathrm{M}-1 、 \mathrm{M}-2$ のそれに比べ高いが、第 2 折点が低いため、M-2 と同様 M・1に比べふくらんだ包絡線となった。

M-3 の第 1 剛性が高くなる要因として、1P 耐力壁の重ね合わせか ら推定しているため、柱脚等の金物の効果が重複すること、また $8 \mathrm{P}$ や実大建物相当の規模になると、部材間のすべり等の影響が $1 \mathrm{P}$ や $4 \mathrm{P}$ に比べ大きくなり、1Pの重称合わせよりも第 1 剛性は低くなる ことなどが考えられる。

\section{5 地震応答解析とその評価}

3 種類の復元力モデルについて地震応答解析を行い、それらの応 答値と振動台実験結果（以下 V-test）との比較から復元力モデルの 妥当性についての検証を行う。入力地震波には神戸海洋気象台波 （NS 成分、最大加速度 818gal）を用いた。応答解析には Newmark $\beta$ 法の増分法（ $\beta=0.25 ）$ を用いた。减衰定数は初期剛性比例型で $5 \%$ とした。

解析モデルはせん断質点系モデル（図 11）であり、各階の剛性は 表 3 に、重量は表 4 に示す。なお、本解析モデルではP- $\Delta$ 効果は考 慮していない。

各モデルと振動台実験結果の最大応答值を表 5 に、各モデルの応 答変位の波形を図 12 に、V-test と M-3 の荷重変形曲線を図 13 に 示す。

最大応答加速度について、V-test が 1267galに対し、M-1 は 1236gal、 M-2 は 1237gal、M-3 は 1171 gal であり、V-test との差は2〜8\%とな つた。最大応答速度について、V-test が 80.6kine に対し、M-1 は 77.5kine、M-2 は 60.9kine、M-3 は67.6kine であり、V-test との差は4 〜24\%程度であり、いずれもV-test より低い値となった。

最大応答変位について、V-test が $94.7 \mathrm{~mm}$ に対し M-1 は $103.4 \mathrm{~mm}$ 、 M-2 は 92.5mm、M-3 は 94.4mm であった。実大静加力実験結果から 作成した M-1 がよく推定できているのは当然と考えられるが、1P モデルの重权合わせから作成した、モデルの精度が低いと考えられ るM-3においてもよく推定できている。

以上の検証結果は、実験結果に基づいているもののあくまで一実 験結果に対する検証であるため、十分な一般性を有するものとはい えないことも明記する必要がある。しかし本論文の検証結果は、耐 力壁要素の静的な復元力モデルの重ね合わせから実大建物の動的挙 動の予測可能性を、十分示唆するものであると考えられる。

\section{6. まとめと今後の課題}

本論文を以下にまとめる。

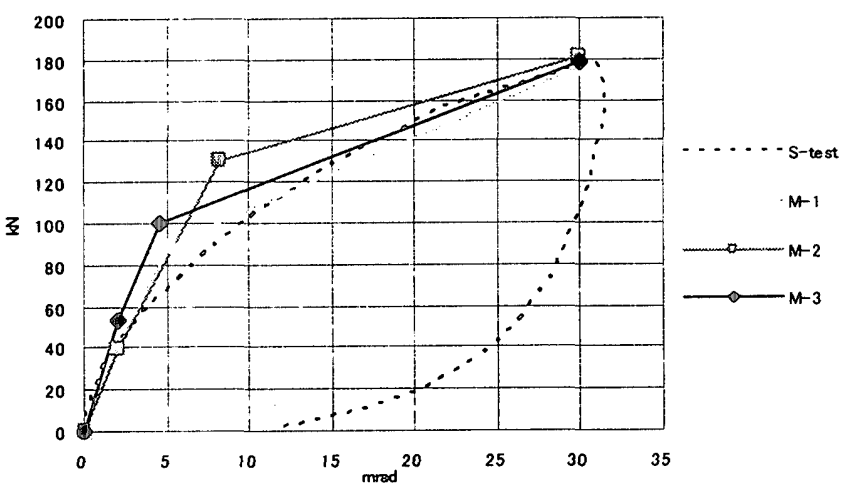

図 10 包絡線モデルの比較

表 33 種類の復元力モデルのパラメタの比較

\begin{tabular}{|c|c|c|c|}
\hline & (a) $\mathrm{M} \cdot 1$ & (b)M-2 & (c) $\mathrm{M}-3$ \\
\hline 第 2 折点 (mrad.) & 5.20 & 8.19 & 4.58 \\
\hline 第 1 则性 (kN/mrad.) & 20.14 & 19.50 & 26.39 \\
\hline 第 2 制性(kN/mrad.) & 15.44 & 14.75 & 18.47 \\
\hline 第 3 剛性( $(\mathrm{kN} / \mathrm{mrad}$ ) & 3.50 & 2.33 & 3.06 \\
\hline $\mathrm{a}$ & 0.27 & 0.28 & 0.36 \\
\hline b & 0.77 & 0.76 & 0.70 \\
\hline $\mathrm{c}$ & 0.17 & 0.12 & 0.12 \\
\hline
\end{tabular}

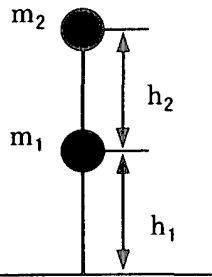

表 4 各階質量および階高

\begin{tabular}{|c|c|c|c|c|}
\hline & \multicolumn{2}{|c|}{ 質量 $(\mathrm{kg})$} & \multicolumn{2}{|c|}{ 階高 $(\mathrm{mm})$} \\
\hline 1 階 & $\mathrm{m}_{1}$ & 9,300 & $\mathrm{~h}_{1}$ & 2,885 \\
\hline 2 階 & $\mathrm{m}_{2}$ & 9,000 & $\mathrm{~h}_{2}$ & 2,930 \\
\hline
\end{tabular}

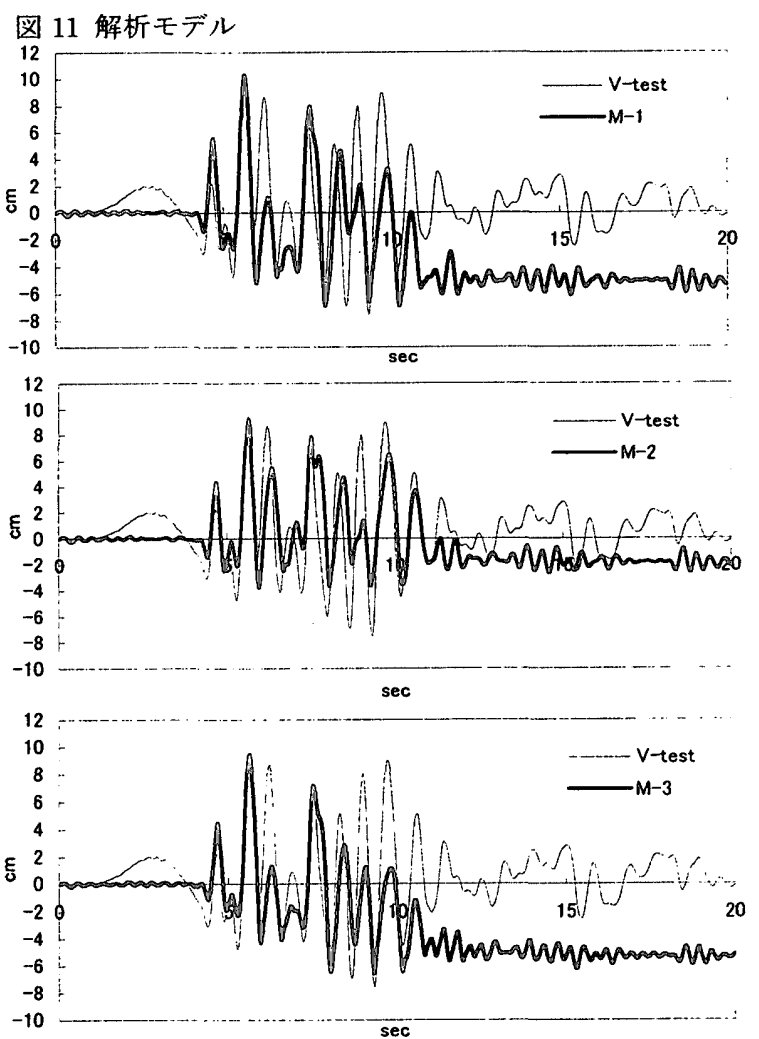

図 12 応答変位波形(M-1～3,V-test) 
1）木質構造物の復元力モデルとしてバイリニア+スリップモデル を用いた。また種々の壁実験のデータベースを作成し、各壁の 仕様に対し復元力モデルのパラメ夕の提案を行った。

2）実大建物を構成する耐力要素の復元力モデルの重ね合わせから 建物全体の復元力モデルの予測する手法の提案を行った。

2）2）の手法を用いて実大建物の復元力モデルを 3 種類（1P 壁か ら予測、8P 壁から予測、実大建物から予測）設定し、地震応答 解析を行った。応答値と実大振動台実験結果を比較したところ、 最大応答変位についてはいずれのモデルも実験結果との差は最 大でも $10 \%$ 程度となった。一実験結果に対する検証であるもの の、バイリニア+スリップのような単純なモデルの組合わせを用 いて、壁の復元力モデルの重ね合わせから実大建物の動的応答の 予測可能性を示唆する結果が得られたと考えられる。

\section{参考文献}

1）坂本功、大橋好光、田中裕臌、宮澤健二、他：軲組構法住宅の実大振動 台実験(A 楝) その 1 4、日本建築学会大会学術請演梗概集、C2、pp.129 $\sim 136 、 1996.9$

2）宮濢健二、大橋好光、坂本功、北野志乃、他：軸組構法住宅の実大振動 実験(B 楝)その 1〜その 3 日本建築学会大会学術講演梗概集、C2、pp.137 $\sim 142 、 1996.9$

3）岸川聡史、小原勝彦、宮澤健二 : 軸組住宅の実大振動実験( $\mathrm{F}$ 棟) 日本建策 学会大会学術講演梗概集、C2、pp.153 156、1996.9

4) I.Sakamoto, Y.Ohashi and M.Shibata:THEORETICAL ANALYSIS OF SEISMIC RESPONSE OF WOODEN DWELLINGS IN JAPAN, Proc. of Pacific Timber Engineering Conference, pp.454 461、1984、506 号、

5）宮澤健二 : 枠組壁構造の非線形心力解析について、第 13 回情報システム 利用技術シンポジウム、pp.277〜282、1990.12

6）大橋好光、坂本功：木造住宅の地震忘答解析 その 2、日本建築学会大会 学術講演梗概集、C、pp.1237〜1238、1985.10

7) 真柄裁、三宅辰哉、五十田博、田守伸一郎、笹川明：枠組壁工法 建築物の地震時最大応答変位に関する考察、日本建築学会構造系論文集、 第 pp. $75 \sim 82 、 1998.4$

8）鈴不舞子、安村基 : 枠組壁工法耐力壁の仮動的奏験と時刻歴地震纫答解 析、日本建築学会大会学術講演梗概集、C1、pp.85 86、2000.9

9）宮澤健二、小原勝彦、宮本俊輔、高木良：実大実験に基づく耐震性能に 関する研究 その 1 3、2000 年度日本建築学会関東支部研究報告集、 pp.181 192、2001.3

10）尾内俊夫、太田外氣晴、諸星史雄、兵庫県南部地震の強震動による枠組 壁構法住宅の振動特性之耐震性の評価、日本建築学会構造系論文集、第 517 号、pp.107〜114、1999.3

11）定方登、藤田昌男、甲斐謙吾 : 石㙜ボード張枠組壁の交番载荷実験（そ の 1)、日本建勧学会東海支部研究報告、pp.193 196、1983.2

12）西川忠、十河哲也、植松武是：北海道における木造在来構法住宅の耐震 性に関する研究（その 2)、日本建築学会北海道支部研究報告集 No.71、 pp.145 148、1998.3

13）三芳紀美子、大橋好光、高橋浩一他 2 名 : 軸組構法住宅用各種壁の静加 力試験および振動台実験（その 1)、日本建築学会大会学術講演梗概集、 C1、pp.199 200、2001.9

14）小比田㳯、笹川明、五十田博：開口を有する石霄ボード及び合板張り枠 組壁工法耐力壁のせん断酎力に関する研究、日本建築学会北陸支部研究 報告集、第 40 号、pp.73 76、1997.7

15）西村彰敏、大木洋一郎、宮澤健二：枠組壁工法耐力壁の強度に及ぼす枠 材樹種、パネル割り付けと釘打ちの影響に関する研究、1999 年度日本建 榮学会関東支部研究報告集、pp.53 56、2000.3

16）大橋好光、田中裕樹、新居健二 : 実大実験による木造軸組構法住宅の耐 震性に関する研究 その 2、日本建築学会大会学術講演梗概集、C1、 pp. 237〜238、1998.9

17）南公人：木質構造における面材張り開口壁の水平せん断耐力評価法、東 京大学大学院 1998 年度修士論文

18）大橋好光、坂本功：開口部を含む在来木造壁の水平せん断実験、昭和 59 年度日本建築学会関東支部研究報告集、pp.21 24、1985.3

19）安達文男、大橋好光、坂本功：在来木造建物の非酎力壁の水平せん断実 験、日本建築学会大会学術講演梗概集（構造系）、pp.2661～2662、1984
表 5 各モデルの応答值

\begin{tabular}{|c|c|c|c|}
\hline & Disp.(mm) & Vel.(kine) & Acc.(gal) \\
\hline (a) V-test & 94.7 & 80.6 & 1267 \\
\hline (b) $\mathrm{M} \cdot 1$ & 103.4 & 77.5 & 1236 \\
\hline (c) $\mathrm{M}-2$ & 92.5 & 60.9 & 1237 \\
\hline (d) $\mathrm{M}-3$ & 94.4 & 67.6 & 1171 \\
\hline (b) / (a) & 1.09 & 0.96 & 0.98 \\
\hline (c) / (a) & 0.98 & 0.76 & 0.98 \\
\hline (d) / (a) & 1.00 & 0.84 & 0.92 \\
\hline
\end{tabular}

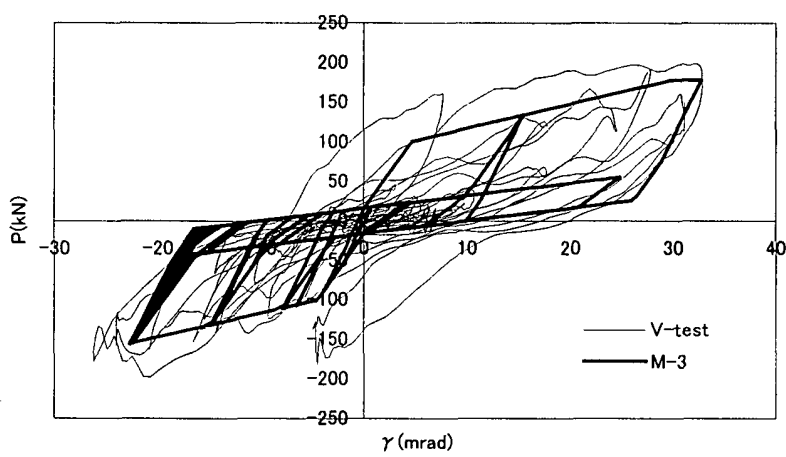

図 13 荷重変形曲線(M-3,V-test)

10

20）半田勝己、筑川明、五十田博、白須万寛 : 部材、接合部を最小単位とす る筋交耐力壁の弾塑性応答解析モデ、日本建築学会大会学術講演公害 集、C1、pp.153〜 154、1998.9

21）河合直人、岡部実、渡辺一正: 在来軸組構法耐力壁の耐震性能（その 2)、 日本建築学会大会学術講演梗概集、C1、pp.135～136、1998.9

22）生田寛、多賀直恒：1,2 階の䀠性バランスが在来軸組構法木造住宅の倒壊 モードに及ぼす影響、日本建築学会大会学術詇演梗概集、C1、pp.291〜 pp.292、1999.9

23）一反田康㤵、岩井哲：木造建物の動的特性に関するデータベース構筑と 応答解析用復元力履歴モデ、日本建築学会大会梗概集、C1、pp.199 200、2000.9

24）平鳴義彦、神谷文夫、畑山義男：耐力壁ラッキング試験における試験法 間の関連性について、日本建築学会大会梗概集、C、pp.1195〜1196、 1986.8

25）大野吉昭、岡部実、传久間博文、下屋数朋千：耐力壁の水平加力試験に おける夕イロッド式と柱脚固定式の比較、日本建築学会大会梗概集、C 1、pp.309〜310、2001.9

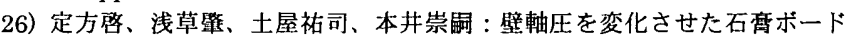
張木枠組壁の耐力・変形性状と履厢特性について（第 3 報）、日本建築学 会東海支部研究報告集、pp.201 204、1988.2

27）五十田博、平野陽子、坂本功、大橋好光、塩谷嘉宏：木造軸組構法の耐 力壁のパネル化に関する研究 その 1 2、日本建築学会大会梗概集、C、 pp113〜116、1991.9

28）落海一哉、安村基 : 枠組壁工法耐力壁の䞂力に及ほす釷間隔の影響、日 本建築学会大会梗概集、C、pp.195 196、1990. 10

29）枠組壁工法建筑物構造計算指針 1992、日本ツーバイフォー建築協会

30) 杉山英男、松本忠: Empirical Equations for the Estimation of Racking Strength of a Plywood-Sheathing Shear Walls with Openings、日本建築学会学術講演 梗概集、pp.89 90、1994.9

31）鈴木秀三、“耐力壁の考元方一面材耐力壁（構造用合板(軸材＋面材）一”、 建築技術、1997 年 9 月号、pp.168 170

32）柴田明徳：最新耐震構造解析、最新建築学シリーズ 9、森北出版、1981 年

（2003年 8 月 13 日原稿受理，2004年 1 月22日採用決定 